\title{
Farewell, Norbert
}

\author{
Aslihan Usumez ${ }^{1} \cdot$ Leon Vanweersch $^{2}$
}

Published online: 9 September 2021

(c) The Author(s) 2021, corrected publication 2022

We were shocked to hear the tragic news that Prof. Norbert Gutknecht passed away on the $19^{\text {th }}$ of July 2021 due to this terrible COVID disease. On behalf of the Editorial Board and all of his coworkers at Lasers in Dental Science, we wish to extend our condolences to his family!

His death is a loss for everyone in the world of laser dentistry. Norbert Gutknecht was the personification of the development and successful introduction of dental laser therapy, or laser supported dental therapy, as he liked to call it. Since 1991, when he released his first academic publication, he was involved in or first author of more than 200 books and articles. He was a founding member and President of the German Society for Laser Dentistry (DGL); one of the first members and President of the International Society for Laser Dentistry (ISLD); co-founder and Scientific Director of the Aachen Dental Laser Center (AALZ) from 1993; co-founder and Scientific Director of the World Academy for Laser Education in Dentistry (WALED) from 2007; and Program Director of RWTH Aachen University's Master of Science in "Lasers in Dentistry" from 2004, as well as Editor-in-Chief of the journal Lasers in Dental Science (LIDS) and Associate Editor of the journal Lasers in Medical Science (LIMS), to name just a few of his most important positions. He was first a research assistant, later (after completing his postdoctoral degree) a senior physician and Vice-Director, and finally Acting Director of RWTH Aachen University's Clinic for Operative Dentistry, Periodontology and Preventive Dentistry. His last professional postings were at the University of Namibia in Windhoek (UNAM), where he served as Director of the Dental School and Associate Dean of the Dental Faculty.

With his magical enthusiasm, but also his unique wealth of evidence-based knowledge, he was able to win over

Leon Vanweersch

leon.vanweersch@icloud.com

Aslihan Usumez

asli_u@hotmail.com

1 Istanbul Dental Academy, Istanbul, Turkey

2 RWTH Aachen University, Aachen, Germany thousands of dentists worldwide for dental laser therapy. Norbert Gutknecht was actively involved in the development, research, training and therapy design of laser dentistry, and championed the field like no other person in the world.

Norbert was like a spiritual father to all of us, and we now have to continue and build on his legacy, just as he always asked us to do.

Norbert, we will never forget you. Rest in peace.

Aslihan Usumez - Leon Vanweersch

Funding Open Access funding enabled and organized by Projekt DEAL.

\section{Declarations}

Conflict of interest Aslihan Usumez and Leon Vanweersch declare that we have no conflict of interest.

Open Access This article is licensed under a Creative Commons Attribution 4.0 International License, which permits use, sharing, adaptation, distribution and reproduction in any medium or format, as long as you give appropriate credit to the original author(s) and the source, provide a link to the Creative Commons licence, and indicate if changes were made. The images or other third party material in this article are included in the article's Creative Commons licence, unless indicated otherwise in a credit line to the material. If material is not included in the article's Creative Commons licence and your intended use is not permitted by statutory regulation or exceeds the permitted use, you will need to obtain permission directly from the copyright holder. To view a copy of this licence, visit http://creativecommons.org/licenses/by/4.0/.

Publisher's note Springer Nature remains neutral with regard to jurisdictional claims in published maps and institutional affiliations. 